\title{
Dinosaur nests at the sea shore
}

SIR - Beach deposits of the Arenisca de Arén Formation ${ }^{1}$ (southern Pyrenees, Maastrichtian, Upper Cretaceous) are rich in dinosaur eggs and bones, distributed over an area of about $15 \mathrm{~km}^{2}$ along the northern flank of the Tremp syncline (Fig. 1). At one locality (Bastús, Lleida) we have estimated the presence of up to 300,000 eggs in a rock volume $\approx 12,000 \mathrm{~m}^{3}$, suggesting some kind of 'site fidelity'.

Dinosaur remains have frequently been reported from marine sediments. Efremov ${ }^{2}$ ing well-preserved dinosaur nests (Fig. 1). Farther down, the red layer passes into shore face sandstones with well-preserved, wave-induced sedimentary structures, forming part of a near-shore environment passing landward into mudflat deposits, occasionally dissected by small channels ${ }^{5}$. As the beach-ridge plain was built up to seaward (progradation), the dinosaurs nested in the exposed sandy sediment.

A huge number of egg shell fragments are scattered along the outcrop (Fig. 2).

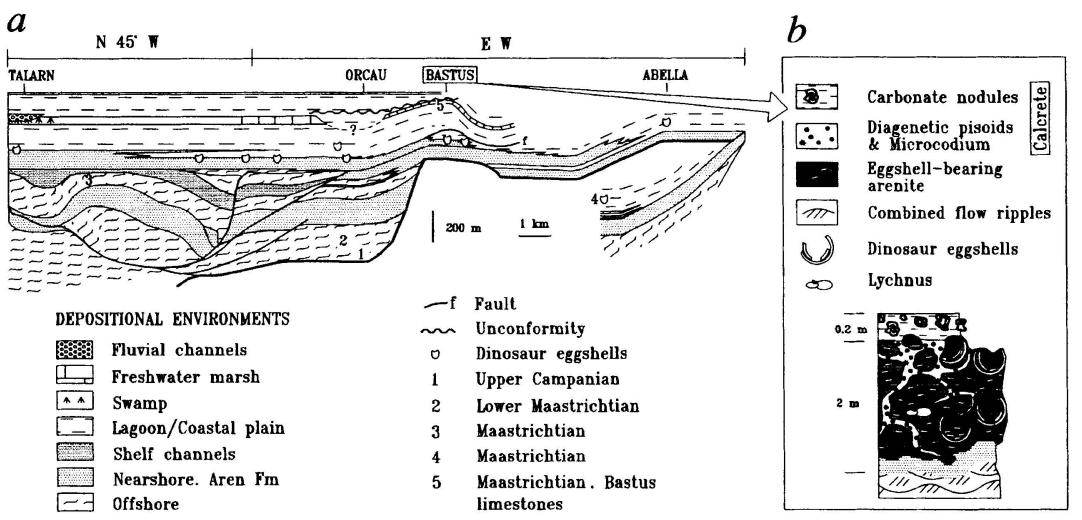

FIG. 1 a, Cross-section through the NW-prograding depositional sequence, Late Campanian and Maastrichtian in age, along the northern flank of the Tremp syncline (South Central Pyrenees, Spain). The succession formed under high terrigenous influx and relative sea-level rise. The sequence passes from coastal plain (Tremp Fm. p.p.) through strand-plain/barrier island (Arenisca de Arén Fm.) to offshore sediments. It overlies nearshore deposits of a similar sequence, which are affected by growth faults ${ }^{5}$. The dinosaur nests have been preserved mainly at the top of the Arenisca de Arén Formation. $b$, Log of the Bastús section. The matrix of the

eggshell-bearing rock is a calcite-cemented, medium-to-coarse-grained arenite of mixed siliciclastic and carbonate grain composition. Carbonate grains comprise different types of worn skeletal fragments dominated by shallow-marine elements, intraclasts as well as dinosaur eggshell debris, and are generally affected by microbial micritization. This, along with the local preservation of relict dripstone and meniscus cement fabrics, suggests that lithification was initiated at the strand line (beach rock). Shoreline progradation then caused the incipiently cemented sand to become exposed to meteoric waters. Diagenesis in the freshwater phreatic environment involved selective leaching of initially aragonitic components and concomitant precipitation of new diagenetic calcite. Further diagenetic alteration before final burial of the sediment occurred in the meteoric vadose zone, as documented by the presence of a variety of petrographic features diagnostic of pedogenic calcrete development. $c$, Aspect of the outcrop.

suggested a marine habitat for some dinosaurs, although these were later interpreted as the remains of individuals that had been washed to the sea. Chanda ${ }^{3}$ proposed a shallow-water marine environment for the dinosaur egg-bearing Lameta Formation of India, however, Shani et al. ${ }^{4}$ conclusively argued for the continental (palustrine) origin of these sediments. Thus, the Arenisca de Arén egg sites represent the first unambiguous evidence of dinosaurs nesting at a sea shore.

The top of the Arén Formation at Bastús is 2-m-thick red sandstone containtion of some nests and bones are well preserved, post-depositional transport can be excluded as a primary cause of fragmentation. Rather, the eggs were destroyed by the animals' nesting and trampling activities and later by paedogenesis (Fig. 1). The nesting probably occurred in the unconsolidated sands of the beach ridge, in a short time interval between beach abandonment

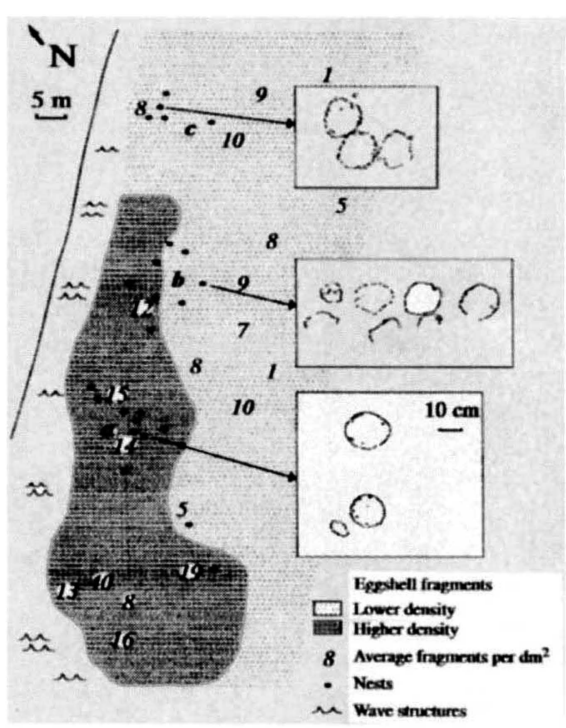

FIG. 2 Map illustrating nest distribution and eggshell density. The preserved nests, probably the last clutches, are in three main clusters. The distance between nests is $1-5 \mathrm{~m}$ (a), 4-6 $\mathrm{m}(\mathrm{b})$ and 3-8 $\mathrm{m}(\mathrm{c})$. The distance between some nests $(1 \mathrm{~m})$ is too short with respect to the presumed body size of the adult dinosaurs, suggesting that the nesting strategy is different from the colonial nesting behaviour described elsewhere ${ }^{6}$.

and early diagenesis (meteoric leaching, incipient lithification and paedogenesis).

The eggshell structure is tubospherulitic, and most of the preserved egg sections show subcircular contours. Some complete eggs from this locality, housed in the Freie Universität, Berlin, have a subspherical shape, with a diameter $\approx 20 \mathrm{~cm}$. The outcrop has yielded the remains of 24 nests arranged in three clusters on a surface $\approx$ $6,000 \mathrm{~m}^{2}$ (Fig. 2). Each nest contains 1-7 eggs, most of them having only two or three preserved eggs, representing portions of nests deposited in a hole dug in the sediment.

The Bastús nests are closely spaced but do not overlap (modal distance $2.5 \mathrm{~m}$; Fig. 2). As the preservation state of the nests is generally good, some factor has precluded the destruction of previous clutches by newcomers. Some territorial behaviour may account for this feature. A high population density and/or scarcity of favourable substratum could explain the observed short distances between nests.

Using a $1-\mathrm{dm}^{2}$ grid in 20 randomly chosen areas (Fig. 2), we calculate that the eggshell material amounts to $\approx 0.5 \%$ of the total rock volume. Given the volume of the sandstone body $\left(12,000 \mathrm{~m}^{3}\right)$ and assuming an average egg size of $20 \mathrm{~cm}$ diameter and $1.45 \mathrm{~mm}$ shell thickness, we estimate
1. Nagtegaal,P. J. C. et al. Sedim. Geol. 34, 185-218 (1983)

2. Efremov, I. A. Priroda URSS 6, 1-18 (1953)

3. Chanda, S. K. J. sedim. Petrol. 33, 728-738 (1963).

4. Shani, A. et al. in Dinosaur Eggs and Babies (eds Carpenter, K., Hirsch, K. F. \& Horner, J. R.) 204-226 (Cambridge Univ. Press, UK, 1994).

5. Díaz-Molina, M. Estudios geol. Vol. extr. Galve-Tremp 69-93 (1987).

6. Horner, J. R. Nature 297, 675-676 (1982). 
that the lithic body contains the remains of some 300,000 eggs. This suggests that the area was a nesting ground, and that the dinosaurs may have returned to this same area during several reproductive seasons.

The Bastús egg site is the result of the nesting behaviour of a dinosaur population living very near the sea shore and may represent a local example of a widespread phenomenon in the Upper Cretaceous of the south-central Pyrenees.

J. L. Sanz, J. J. Moratalla

Unidad de Paleontologia, Facultad de

Ciencias, Universidad Autónoma,

Cantoblanco, 28049 Madrid, Spain

M. Díaz-Molina, N. López-Martínez,

0. Kälin

Facultad C. Geológicas, I.G.E. (CSIC),

Universidad Complutense,

28040 Madrid, Spain

M. Vianey-Liaud

Institut des Sciences de l'Evolution,

Université de Montpellier II,

34095 Montpellier Cedex 05, France 